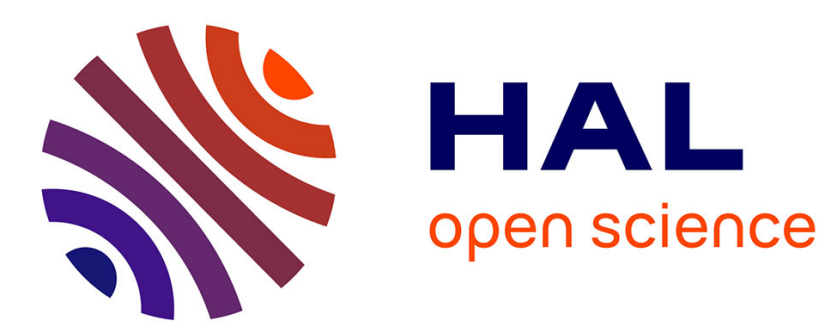

\title{
Soil exploration and resource acquisition by plant roots: an architectural and modelling point of view
}

\author{
Claude Doussan, Loïc Pagès, Alain Pierret
}

\section{To cite this version:}

Claude Doussan, Loïc Pagès, Alain Pierret. Soil exploration and resource acquisition by plant roots: an architectural and modelling point of view. Agronomie, 2003, 23 (5-6), pp.419-431. 10.1051/agro:2003027 . hal-00886193

\section{HAL Id: hal-00886193 https://hal.science/hal-00886193}

Submitted on 1 Jan 2003

HAL is a multi-disciplinary open access archive for the deposit and dissemination of scientific research documents, whether they are published or not. The documents may come from teaching and research institutions in France or abroad, or from public or private research centers.
L'archive ouverte pluridisciplinaire HAL, est destinée au dépôt et à la diffusion de documents scientifiques de niveau recherche, publiés ou non, émanant des établissements d'enseignement et de recherche français ou étrangers, des laboratoires publics ou privés. 


\title{
Soil exploration and resource acquisition by plant roots: an architectural and modelling point of view
}

\author{
Claude DOUSSAN ${ }^{a *}$, LoḮ PAGÈs $^{b}$, Alain PIERRET $^{c}$ \\ ${ }^{a}$ INRA - Unité Climat, Sol et Environnement, Domaine Saint-Paul, Site Agroparc, 84914 Avignon Cedex 9, France \\ ${ }^{b}$ INRA - Unité Production et Systèmes Horticoles, Domaine Saint-Paul, Site Agroparc, 84914 Avignon Cedex 9, France \\ ${ }^{\mathrm{c}}$ CSIRO - Land \& Water, GPO Bbox 1666, Canberra ACT, Australia
}

(Received 9 July 2002; accepted 7 May 2003)

\begin{abstract}
We provide a brief overview on soil exploration and resource extraction by roots during the course of plant development. First, we examine how roots explore the soil volume in relation with the heterogeneity of soil conditions. We then consider resource acquisition by roots and root systems, taking into account the root system's heterogeneous functioning and its variable degree of plasticity. In extensive, complex and dynamic systems such as root systems, processes of soil exploration and resource acquisition can be analysed through the unifying point of view of root system architecture. We exemplify how a modelling approach based on the concepts of functional architecture has potential to provide sharper insight into the soil exploration/utilization processes.
\end{abstract}

root system / model / architecture / review / soil exploration

Résumé - Exploration du sol et acquisition des ressources hydro-minérales par les systèmes racinaires des végétaux : un point de vue architectural et de modélisation. Nous présentons une courte revue décrivant les grandes étapes de colonisation et d'exploitation du sol durant le développement de la plante. Nous montrons tout d'abord comment les racines explorent le sol en interagissant avec l'hétérogénéité des conditions de sol (du point de vue des nutriments ou des contraintes à la croissance). De cette vision essentiellement géométrique (exploration), nous passerons à l'exploitation des ressources par les racines en considérant l'hétérogénéité de fonctionnement du système racinaire ainsi que son plus ou moins fort degré de plasticité. Ces processus d'exploration et d'exploitation du sol seront présentés sous l'angle unificateur de la prise en compte de l'architecture racinaire. Dans des systèmes complexes et très dynamiques, comme un système racinaire, nous montrerons, avec des exemples récents, comment la modélisation, fondée sur une architecture fonctionnelle, permet d'aller plus loin dans la compréhension des processus d'exploration/exploitation du sol par les plantes.

système racinaire / modélisation / architecture / revue / exploration du sol

\section{INTRODUCTION}

Root systems of terrestrial plants have a functional importance in resource storage, synthesis of growth regulators, and propagation. However, the primary functions of root systems are anchorage of the plant in the soil and the acquisition of soil resources, i.e. mainly water and mineral nutrients [26]. In soils, roots are exposed to highly heterogeneous and variable conditions both in space and time. Constraints to root growth often originate from this variability in resource availability (water and nutrients) and physico-chemical properties. The development and propagation of an extensive and structured root system represents plants' evolutionary response to the spatio-temporal variability of resources availability and the associated constraints to growth [30]. The extension in space and time of the root system obeys developmental rules susceptible of modulation by interaction with the environmental conditions. Moreover, the root system should be viewed as a population of roots with varying, although coordinated, morphological, and physiological (particularly uptake) properties. In addition, physiological heterogeneity also exists along single root axis in relation to ageing.

In this review, we first examine how roots explore the soil volume in relation to the heterogeneity of soil conditions. From this purely geometrical viewpoint of soil exploration, we then consider the impact of roots' functional heterogeneity and plasticity on the root system's overall ability to use soil resources. In extensive, complex and dynamic systems such as 
root systems, processes of soil exploration and resource mining can be analysed through the unifying point of view of root system architecture. We exemplify how a modelling approach based on the concepts of functional architecture, has potential to provide sharper insight into the soil exploration/utilization processes. We also show how such a modelling approach represents a way to quantify soil exploration by roots at scales ranging from the individual root to the entire root system.

This review is specifically focused on root architecture, the influence of mycorrhizae on nutrient uptake is not discussed. The influence of mycorrhizae on nutrient acquisition by plants is well know and has been widely reported (see $[50,93])$. In addition, it has been shown that mycorrhizae can modify the overall root system architecture [33]. Likewise, the modification of rhizospheric soil by root-induced chemical processes, e.g. modifications induced by specialised roots such as cluster roots [75], is not discussed in this review (see [31] for a review of these processes).

\section{ROOTS SYSTEMS AS A RESPONSE TO THE HETEROGENEOUS DISTRIBUTION OF RESOURCES AND SOIL CONSTRAINTS TO ROOT GROWTH}

\subsection{Soil water and nutrients heterogeneity in time and space in soils}

The availability of hydro-mineral resources is variable at spatial scales ranging from a few mm ('hot spots', [64]), a few centimeters (gradients in $\mathrm{O}_{2}$, water availability, $\mathrm{pH}$, nutrient status - [45]) to several meters. This variability in resource availability can be related to e.g. variations in soil texture [96], topography, climate, vegetation, or soil management. The subterranean activity of soil fauna can create localised zones of fertile loose soil in otherwise poor soil horizons [45, 66]. Heterogeneous patterns may persist in time from a few days to several years. For example, a burst of mineralization may occur for some days and induce nitrate leakage into deeper soil horizons [83], while phosphate enriched patches may remain immobile within a few centimetres for years [45]. Snow thawing in spring flushes mobile nutrients accumulated in surface horizons. In such situations, roots must respond rapidly to the temporal pulse of resources before they are leached away from the root zone.

Examples of variations in nutrient availability under natural soil conditions, at the root scale, are given by Jackson and Caldwell [34] and Robinson [72]. These authors studied the distribution of mineral nutrients (extractable phosphate, nitrate and ammonium) in a sagebrush-steppe (dominated by Artemesia Tridenta) in $0.5 \times 0.5 \mathrm{~m}$ plots. Phosphate exhibited a strong spatial variability with concentrated patches (around $31 \mathrm{mg} \cdot \mathrm{kg}^{-1}$ ) and less concentrated zones (around $20 \mathrm{mg} \cdot \mathrm{kg}^{-1}$ - Fig. 1) and strong positive associations with other variables such as soil organic matter, potassium, nitrification and net $\mathrm{N}$ mineralization. Nitrogen compounds $\left(\mathrm{NH}_{4}\right.$ and $\left.\mathrm{NO}_{3}\right)$ varied substantially too (386 and $116 \%$ respectively) but were less spatially dependent to other variables than P. As Robinson [72] pointed out, patchiness is more likely to occur in soils for

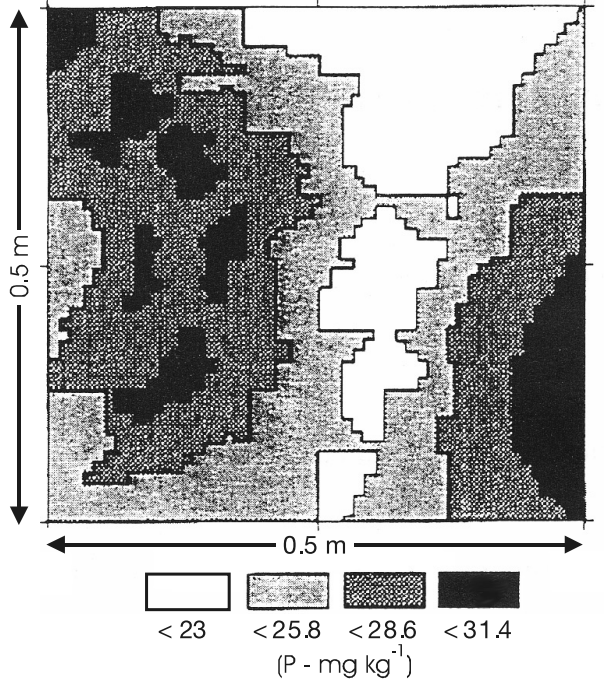

Figure 1. Spatial distribution of phosphate in the topsoil of a $0.5 \times$ $0.5 \mathrm{~m}$ area of sagebrush steppe. Phosphate concentration scale in $\mathrm{mg} \cdot \mathrm{kg}^{-1}$ is shown as shaded boxes (from [34]).

less mobile ions, such as $\mathrm{P}$. In a situation of $\mathrm{P}$ availability such as the case illustrated in Figure 1, different parts of a single root system and even single roots may experience very different $\mathrm{P}$ concentrations. This natural variability may be enhanced in cultivated soils, depending on agricultural practices. At the field scale, in a highly managed (highly fertilised and irrigated) salad crop (lactuca sativa), $\mathrm{N}-\mathrm{NO}_{3}$ concentrations ranged between 20 and $200 \mathrm{~kg} \cdot \mathrm{ha}^{-1}$ [6] with mostly non-normal distributions at different sampling dates. Depending on the sampling date, spatial patterns of concentrations were more or less expressed. In particular, these authors showed that spatial variability of nitrate was time dependent; the locations with the highest initial concentrations retained the highest values with time (and conversely), but this correlation weakened and finally vanished after 2-3 months under these particular crop/agricultural and climatic conditions. Tillage in cultivated systems seems to have no effects on variability [72], but tends to reduce soil patchiness by increasing the patches size.

In conjunction with resource heterogeneity, root systems have to cope with the contrasting behaviour of soil nutrients. Some ions are relatively mobile (such as nitrate) and can move for some distance (i.e. centimetres) from the bulk soil towards the roots. They can be taken up by mass flow and diffusion. Others nutrients (e.g. phosphate) diffuse much more slowly in soil, due to interactions with the solid phase, and uptake necessitate that roots (or mycorrhizae) intercept the nutrient (depletion zone around roots within the millimetre range - [31, 37, 50]). For fast growing species (such as annual crops) this implies a continuous exploration of new soil domains where less mobile nutrients have not already been depleted by root uptake [47].

Last but not least, the pattern of variability of the hydromineral resources also differs in time and space between the different resources. For example, on the one hand, water might 
be available at depth, while shallow horizons are relatively dry. On the other hand, mineral nutrients (e.g. phosphate, [44]) are often more available in the surface horizons.

\subsection{Heterogeneity of soil constraints to root growth}

Physico-chemical conditions in soils may adversely affect root exploration of the soil. As for nutrients, adverse conditions vary in time and space, and roots need to develop strategies to adapt or avoid such conditions.

Among chemical stresses, it seems that strongly acidic subsoils, with $\mathrm{pH}$ less than 5 , represent one of the most important limitations to root penetration [28]. In this case, in relation with $\mathrm{pH}$ dependent solubility of ions and geochemical reactions, roots may be exposed to severe $\mathrm{H}, \mathrm{Al}, \mathrm{Mn}$ toxicity and $\mathrm{Ca}, \mathrm{Mg}, \mathrm{Mo}, \mathrm{P}$ deficiencies. Root growth will then be restricted to the thin topsoil.

Aeration of the soil can also restrict soil exploration by roots. Temporary flooding (e.g. heavy seasonal rainfall on poorly draining soils) can induce a dramatic drop of soil oxygen concentrations (from $\sim 20 \%$ to a few percent) within a few hours to a few days, depending on the temperature and biomass respiration [21]. Except for wetland plant species, when roots get trapped in oxygen depleted soil, they stop growing and eventually die [1]. Fine textured subsoils with a shallow water table are characterised by permanent more or less anoxic/reducing conditions. Roots of most plant species are unable to colonise such soils. Soil temperature is also of major importance to soil colonisation by roots [12]. Temperature gradients with soil depth exist throughout the year and the highest range of temperature variations is in the surface layers [9]. Management of cultivated soils (e.g. tillage or irrigation) modifies the soil thermal regime. Optimal, minimum and maximum [5] temperatures for root growth vary depending on species and their origin $\left(\sim 17\right.$ to $35{ }^{\circ} \mathrm{C}$ [54]). The downward penetration rate of the rooting front varies with soil temperature and a good correlation between this penetration rate and a particular soil isotherm is sometimes observed [38]. Temperature and temperature gradients affect not only root growth but also root initiation, branching and orientation $[5,38,39]$.

Finally, one of the most common physical limitations to soil exploration by roots is the presence of zones of high mechanical resistance [32]. Zones of high soil strength can originate from compaction, which induces an increase in bulk density (plow pan or subsoil compaction due to tillage or wheel traffic), or from a decrease in water content [2]. High soil strength can also be related to specific, genetic, soil horizons (indurated zones, duripans, fragipans, ortstein...) [3]. In cultivated soils, the location and thickness of high strength zones vary during the growing season [8]. Increases in soil strength reduce root growth and the average number of laterals on primary axes [3]. Soil structure of high strength zones is of prime importance to root penetration. In such zones, roots tend to follow cracks and (bio) pores in which they can fit. It was shown that roots of a new crop (corn) re-colonised pores from the preceding crop (alfalfa) [68]. In hardsetting soils of clay B-horizon, Stewart et al. [79] showed that roots grew in macropores, but a large proportion $(80 \%)$ was also located in the soil within $1 \mathrm{~mm}$ of macropores, a zone defined as the macropore sheath. Pierret et al. [66] and Pankurst et al. [63] showed that the chemical and biological properties of this macropore sheath and of small aggregates associated with roots located within macropores differed largely from the bulk soil (for example, bacteria were 5-10 times greater in the macropore sheath and showed a greater metabolic activity; $\mathrm{C}$, $\mathrm{N}$, and $\mathrm{P}$ concentrations showed higher levels in the macropore sheath).

\subsection{Roots and root system architecture}

As they grow, plants must adjust to the spatio-temporal variability of resources availability and constraints to root growth. The root system development represents plants' evolutionary response to this spatio-temporal variability [30]. The overall length of mature plants' root system might be quite important and values of 1 to more than 10 kilometres have commonly been reported (up to $500 \mathrm{~km}$ for 16-week-old winter rye plant) $[16,40]$. Maximum rooting depths are also highly variable among species and biomes (from $0.3 \mathrm{~m}$ for some tundra species up to $68 \mathrm{~m}$ for Boscia albitrunca in Kalahari Desert): trees, shrubs and herbaceous plants, (bulked as functional groups for a wide range biomes) have been reported to have an average rooting depth of 7, 5 and $2.6 \mathrm{~m}$ respectively [76].

It has been recognised for quite a long time that the appearance of root systems in situ (e.g. dominance of the main axis, branching pattern...) can vary greatly, even within species, and be quite complex (Fig. 2 - [7, 41, 91]). The 3-dimensional, dynamic, development of the root system within the soil volume is on the one hand, genotypically driven, and on the other hand, environmentally influenced, as the heterogeneity of resource availability constrains root growth

Roots can be classified into three main categories according to their ontogenesis: primary, nodal and lateral roots [30, 39, $60]$. The primary root differentiates from the seed's radicle and leads to a single-axis root system, or taproot system, with dominant vertical root growth (gravitropism) that emerges first. Adventitious (or nodal) roots differentiate from organs other than roots (e.g. rhizomes, stems, leaves...) and are initiated at precise locations (near stem nodes for example) with a defined temporal pattern. They are often abundant and give rise to a fibrous root system. Adventitious roots are much less sensitive to gravitropism than primary roots [39]. The ability to produce adventitious roots is a genotypic feature [73b]. Lateral roots originate from the branching of a parent axis, generally at right angle, and differentiate from parent roots younger tissues, at some distance from the apex. This process results in a branching front which follows the parent root's apex (acropetal branching). Even when acropetal branching is the dominant branching process, some lateral roots may appear out of the main sequence, differentiating from older tissues near the base of the tap root for example. The maximum number of branching orders seems to be a genotypic feature. Branching can also develop by reiteration. In this process, the parent axis duplicates into two (or three) axes of the same morphological type and creates forks in the root system. Vercambre et al. [87] observed that, in the plum tree, reiterations occurred periodically and profoundly affected the architecture of the root system. 


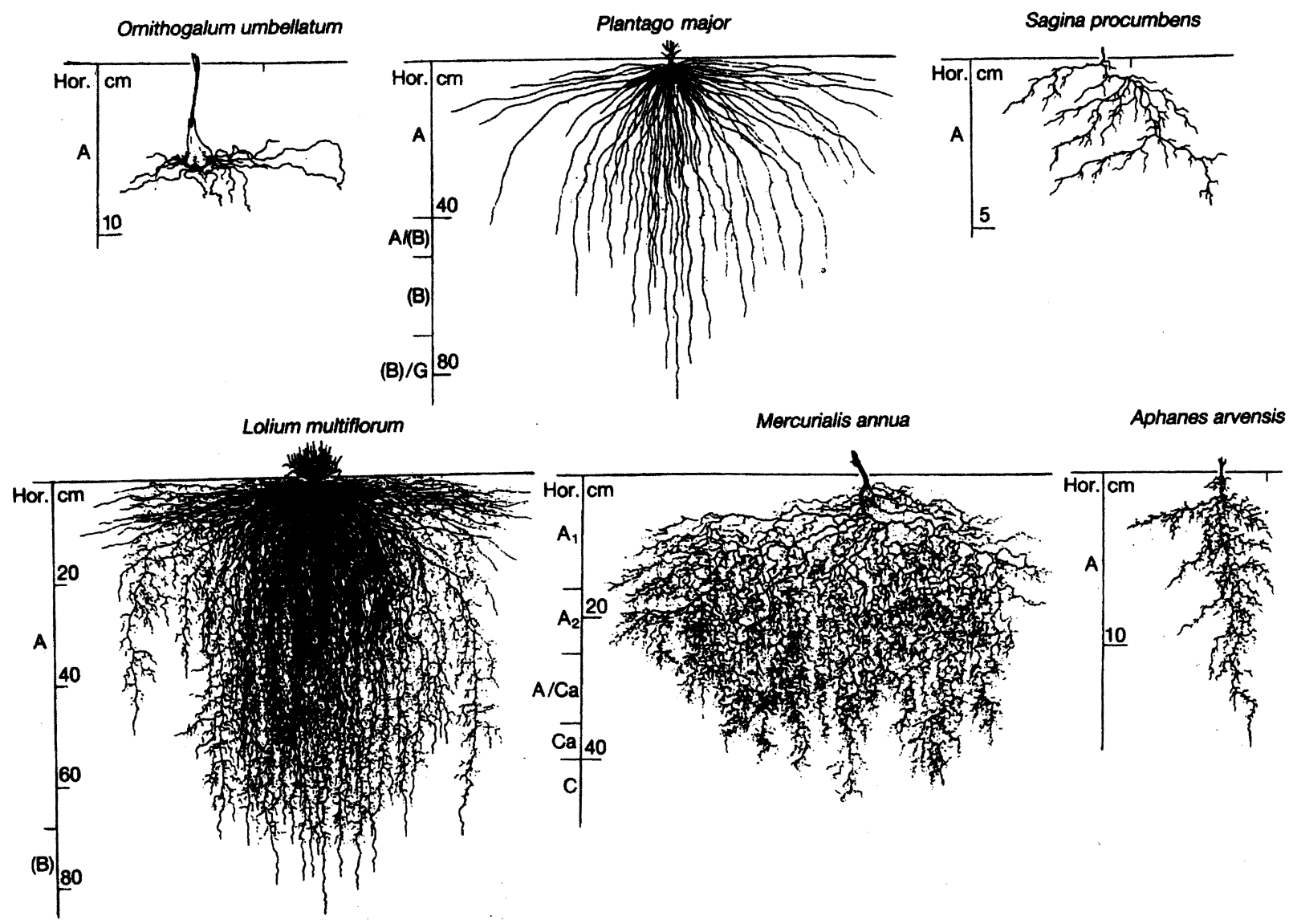

Figure 2. Example of contrasted root systems. On the top row, root systems are little branched, while more profusely branched on the bottom row. Increasing dominance of a single main axis from left to right (from [41]).

The primary root system evolves from the growth and branching (first, second, third...order laterals) of the primary vertical root. Depending on the extension of laterals relative to the primary axis, the morphology of the root system will vary between taprooted and diffuse or fibrous (Fig. 2). These root system types are often found in dicotyledon species. Adventitious root systems are characterised by a large number of root axes originating from the stem base, or from a portion of the stem. They are generally not strongly gravitropic but quite sensitive to water and temperature tropism. Adventitious root systems are typical of monocotyledon species. In a number of plant species (e.g. cereals), the primary root system will dominate the early growth stages while the adventitious root system will take over in older plants.

The respective importance of the primary and adventitious root systems, i.e. the relative growth rates of main axes and laterals, the number of branching orders, etc., varies across plant species. Hence, different plant species develop different soil exploration strategies. Figure 3 exemplifies such differences between a monocotyledon and a dicotyledon species (maize and alfalfa). As maize emits nodal roots throughout its vegetative phase, shallow soil horizons are repeatedly explored and mined by these new roots and their branches. In the case of alfalfa, shallow soil horizons are explored by a single

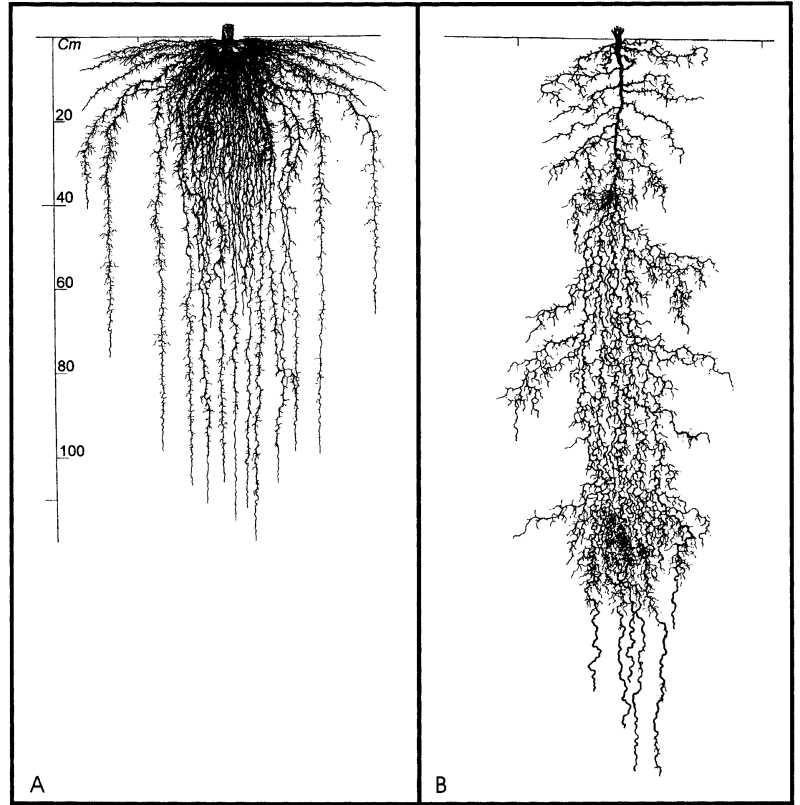

Figure 3. Difference of rooting pattern between maize (A) and alfalfa (B) (from [41]). 
generation of branch roots, with much less new roots emitted in time than for maize.

\section{A QUANTITATIVE VIEW OF SOIL EXPLORATION BY ROOT SYSTEMS}

\subsection{Modelling of root system architectures}

Conceptually, the modelling of root system architecture is based on describing root systems as sets of connected axes in a 3D space. Existing models of root system architecture include variable degrees of dynamic complexity.

\subsubsection{Static modelling of root systems}

The static models describe the branching pattern within the root system architecture by means of synthetic descriptors. Fractal geometry is an example of this approach. This non-Euclidian geometry permits to describe how roots fill the soil space using a non-integer dimension (the fractal dimension $D$ ). This approach's underlying assumption is that the root system is self-similar across a large range of space scales, a property often exhibited by root systems [81]. D has been shown to vary between genotypes, plant age and growth conditions [80]. Fractal geometry also proved useful to estimate the total size of root systems based on measurements of basal roots [82]. Topological modelling is another synthetic approach. It takes into account and globally describe the way root systems branch [26]. In this case, the root system is described by a set of links (a link connects an apex to a branching point or two branching points) and characterized by some topological parameters (for example, the number of links along the path between an apex and the collar of the root system). The topology of root systems will vary from a herringbone pattern (i.e. all branches derives from the same main axis) to a dichotomous pattern (i.e. equiprobable branching on all links). Topological modelling is a fruitful approach for describing the global implications of contrasted branching patterns (herringbone vs. dichotomous) in relation with functional properties and root system optimisation (i.e. trade-off between carbon allocation to roots and efficiency of a root system process).

\subsubsection{Dynamic modelling of root systems}

Dynamic models of root system architecture simulate growing root systems on the basis of simple production rules (for a review see $[46,58,59]$ ). This approach puts the emphasis on the invariance of basic developmental processes. Such a modelling approach really emerged about a decade ago [15, $48,61]$ and became possible with the increasing power of computers. Virtually grown root systems are represented by a set of connected root segments. The root system development is simulated in discrete time steps by applying the basic morphogenetic production rules to the existing root system. These rules are: (i) emergence of new main axes (radicle, seminal or adventitious roots), (ii) growth of the axes (including elongation and growth direction - gravitropism...), and (iii) branching (new lateral axes). Apart from these three basic processes, other processes can be taken into account: (iv) decay and abscission of roots and (v) radial root growth.
The dynamic modelling approach considers different root categories which generally, correspond to the branching order. Different root types will show very different developmental characteristics (e.g. appearance, growth and branching). The classification of root types is based upon several criteria reflecting morphogenetic properties [58]: growth rate, growth duration, branching ability and density, tropism, radial growth... For example, Vercambre et al. [87] considered 6 root types to dynamically model the root architecture of plum trees. The distinctions they made were based on the nature of roots (woody or not), the axial growth (finite or indefinite), radial growth (presence or absence), the maximal length, and the decay (abscission or perennial).

Basic developmental rules need to be parameterized for each root type and depend on the species investigated. For example, continuous emission of nodal roots by cereals is a highly organized sequence in space and time that can be described by thermal time or leaf number [39, 61]. Growth direction may be largely influenced by gravitropism or plagiotropism, the influence of which is highly variable among root branching orders or nodal/seminal roots $[47,60]$. Branching is generally represented by an acropetal sequence (with a fixed distance of emergence behind the apex or a maturation time lag of the primordia), but some species show lateral roots growing out of this sequence. These late lateral roots generally appear near the base of the tap root (e.g. rubber tree, blue lupin). They have a long life span and are important in the recolonisation of superficial soil layer. Branching can also develop by reiteration, a process that should be considered particularly for trees.

These dynamic models include a stochastic description of some processes (e.g. growth direction and soil strength, intrinsic variability of growth rates, radial branching angles...). Dynamic architectural models provide realistic 3D visualizations of root systems (Fig. 4). Each segment of the simulated root system contains some information about its 3D coordinates, age, diameter, root type, etc. Both annual and perennial plants have been modelled and parameterised using dynamic architecture models: Lupin [24], wheat [15], Maize [61], bean [48], Plume tree [87], Oil-Palm [36], rubber-tree [62], pine (Japanese red pine) [81b].

\subsubsection{Modelling of the interactions between root systems and their environment}

Root system models offer an opportunity to integrate, from the root segment to the root system levels, the impact of heterogeneous soil conditions on root growth. Hence, interactions between root systems and their environment can be modelled. The models developed by Somma et al. [77] and Dunbabin et al. [24] integrate a great diversity of environmental conditions and allow to simulate their impact on root system development.

Some models incorporate the influence of soil temperature on root growth or root emission, using a thermal time scale $[15,61]$ or a reduction coefficient applied to optimal root growth rates [11]. The effect of soil strength has also been included (Fig. 5), by means, generally, of indirect variables such as soil bulk density or water content $[11,57]$ combined with empirical functions which reduce optimal growth rates 


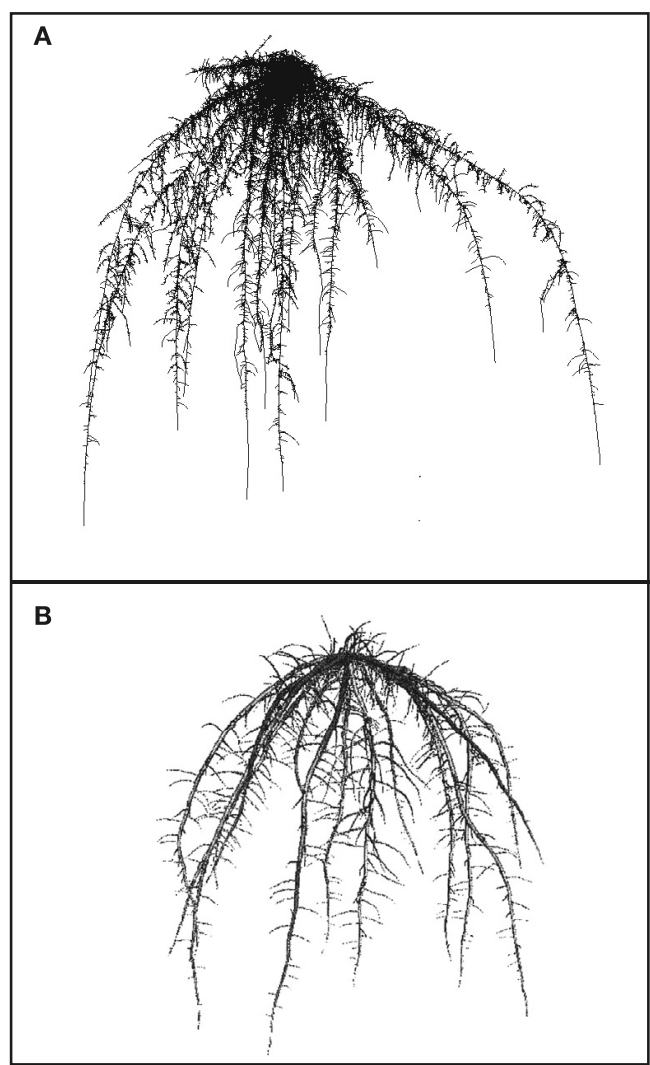

Figure 4. Examples of 3D root systems simulated by architectural models. (A) Maize (from [61]) and (B) bean (from [45]).

and alter root growth direction. Somma et al. [77] introduced the effect of nutrient concentration using growth rates linearly correlated to an optimal range of concentrations. Recently, Tsutsumi [81b] introduced the influence of hydrotropism by including a sensing of the water flux at the root tip which modulates the bending of the root.

\subsection{Using architectural models to quantify soil exploration by root systems}

Most commonly, root uptake potential, is assessed on the basis of synthetic descriptors such as the root density (in term of length, biomass or surface area... per unit soil volume). This descriptor is indicative of soil exploration by roots and, if one can assume that roots are regularly distributed within the soil, an average distance between roots can be derived from root density measurements (Tab. I). The average distance between roots is often used in water and nutrient uptake simulations to define the outer cylinder of soil accessible to the roots $[14,74,94]$. However, in real situations, the assumption of a regular distribution of roots does not hold. Hence, global parameters such as root depth or root density are not sufficient to investigate in detail the development and functioning of root systems. Root distribution within the soil has a strong influence on resource acquisition [46, 58, 59]. Consequently, it is necessary to include detail of root architecture and growth

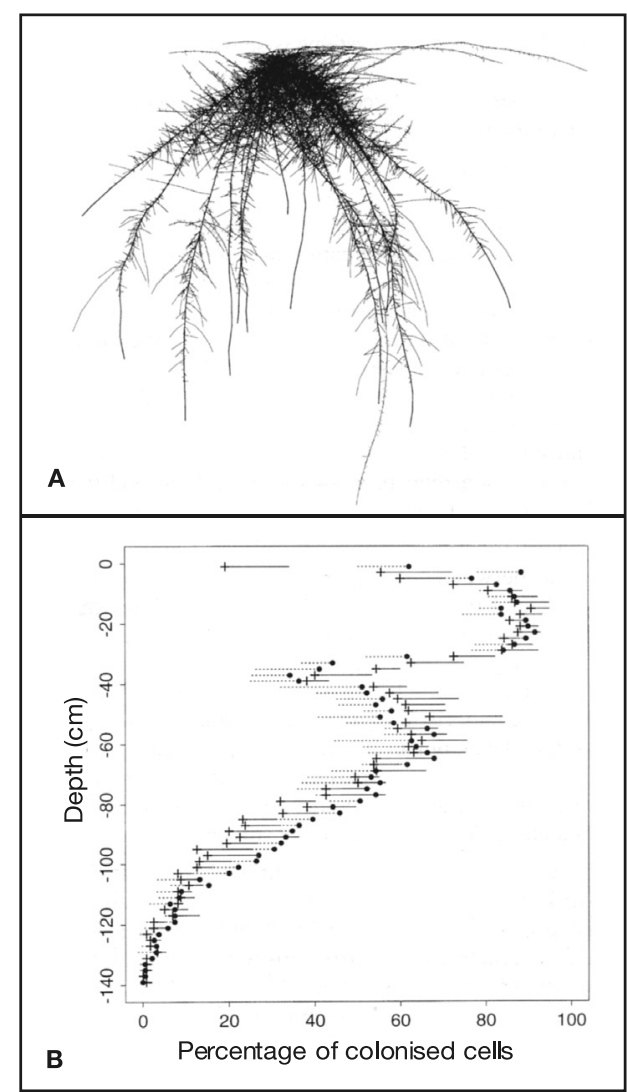

Figure 5. Simulation of maize root system architecture interacting with the environment. A plough pan layer impedes root growth at $35 \mathrm{~cm}$ depth. (A) General morphology of the simulated maize plant. (B) Simulated $(+)$ and observed $(\bullet)$ root profiles, obtained by counting the number of colonised cells $(2 \times 2 \mathrm{~cm})$ on vertical grids. The horizontal bar represents one standard deviation (from [57]).

dynamics to gain sharper insight into the soil exploration/utilization processes.

Models of root system architecture can help to better understand soil exploration by plant roots by taking into account environmental constraints to growth, as previously discussed,

Table I. Root distribution and average distance between roots of three crop species (adapted from Jungk, 2002 [37]).

\begin{tabular}{lcccccc}
\hline Soil depth & \multicolumn{3}{c}{$\begin{array}{c}\text { Root length density } \\
\left(\mathrm{cm} \cdot \mathrm{cm}^{-3}\right)\end{array}$} & $\begin{array}{c}\text { Average half distance between } \\
\text { roots }(\mathrm{cm})\end{array}$ \\
\hline \multirow{3}{*}{$0-30$} & Wheat & Maize & Spinach & Wheat & Maize & Spinach \\
\cline { 2 - 7 } $30-60$ & 8.2 & 3.8 & 2.3 & 0.2 & 0.3 & 0.4 \\
$60-90$ & 1.7 & 1.5 & 0.06 & 0.4 & 0.5 & 2.3 \\
$90-120$ & 0.7 & 0.1 & - & 0.7 & 1.8 & - \\
$120-150$ & 0.27 & 0.01 & - & 1.1 & 5.6 & - \\
$150-180$ & 0.03 & - & - & 3.2 & - & - \\
\hline
\end{tabular}

Total root length $\left(\mathrm{km} \cdot \mathrm{m}^{-2}\right)$

$\begin{array}{llll}0-180 & 36 & 17 & 7\end{array}$ 


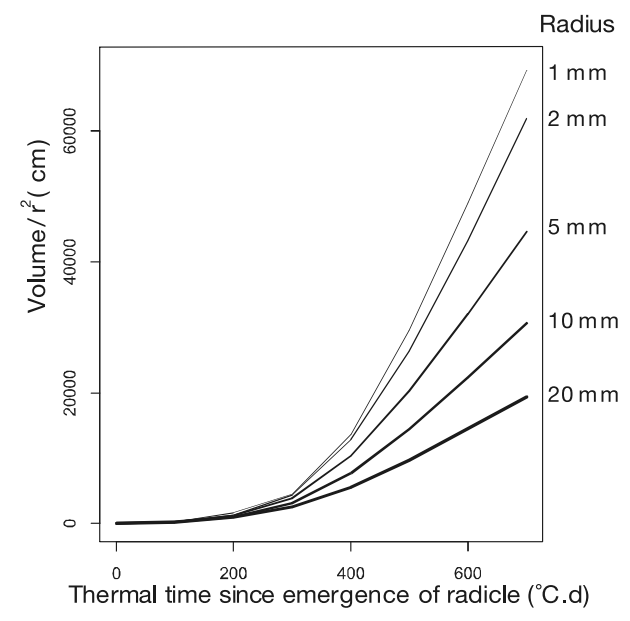

Figure 6. Volume of soil explored by a simulated root system of maize (cf. Fig. 4) for an hypothetical radius of root influence (from 1 to $20 \mathrm{~mm}$ ) in the soil. The soil volume explored by the roots is normalised by the (radius) $)^{2}$ in the figure and represents an effective length of roots in soil not influenced by other roots. The decrease of the normalised prospected zone with increasing radius of influence is due to the increasing overlapping of prospected soil zones by different roots.

but also by giving a quantified view of the soil volume that the roots can access or influence. This is possible since architectural models include full parameterisation of the 3D geometry.

In a first approach, the soil influenced by roots can be investigated by assuming that it is a cylinder of fixed radius centred on the root. This provides a crude estimate of the geometrical properties of a root system independently from any process (i.e. the zone influenced could be a 'rhizospheric' zone, a zone of nutrient depletion, of water depletion...). An example of calculation of the soil volume accessed by maize roots as a function of time of growth and radius of influence is shown in Figure 6. This figure shows that if larger radii of influence globally lead to a bigger zone of influence, they also give rise, with time, to increasing overlap between depletion zones of the different roots. This means that more branch roots will penetrate a zone already influenced by another root as the radius of influence increases. This pattern of soil exploration and interaction between roots derives from interactions between growth rates (i.e. the rate at which a branch root can escape from a zone already exploited), branching density and angle of emission, and the way main axes (nodal roots) are emitted and grow (i.e angle of emission, gravitropism).

A more dynamic view of soil exploration, focused on nutrient acquisition, can be gained by considering the diffusion of nutrients to the roots [70]. In this case, the radius of the depleted volume changes with time (the elapsed time since the root first appeared at some location within the soil volume) and is expressed as [29]:

$$
R_{d}=r+2 \sqrt{D_{e} t}
$$

where $R_{d}$ is the radius of the depleted zone, $r$ the radius of the root segment, $D_{e}$ the effective diffusion coefficient of the ion in soil and $t$ the time period of root growth.

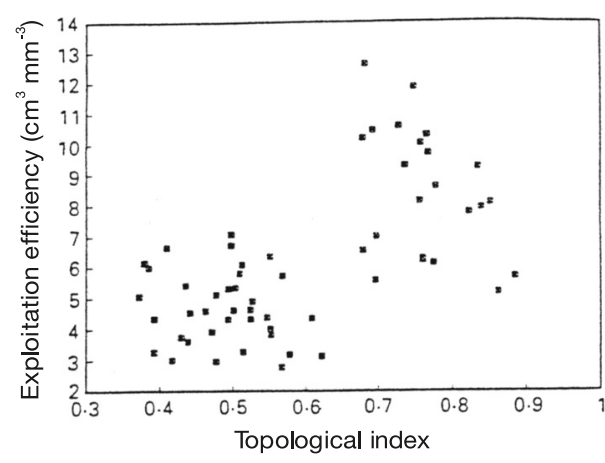

Figure 7. Exploitation efficiency of a root system (defined as the volume of soil exploited per unit root tissue volume) increase with the increase of topological index of simulated root systems. High values of the topological index represent little-branched (herringbone) root systems; low values represent dichotomous branching pattern. The zone of soil exploited increases with time according to diffusion of the mobile resource (diffusion coefficient $=10^{-7} \mathrm{~cm}^{2} \cdot \mathrm{s}^{-1}$, similar to nitrate). The simulation was performed with a range of other architectural characteristics, which explains the scatter of the points (from [26]).

At the root system scale, using topological modelling, Fitter [26] predicted that for mobile nutrients $\left(D_{e}>10^{-7} \mathrm{~cm}^{2} \cdot \mathrm{s}^{-1}\right)$, such as nitrate, herringbone topologies would be more efficient in exploiting the nutrient (Fig. 7). This result is related to the fact that herringbone type root systems produce a few order of laterals, which are characterised by low growth rates and limited extension from the zone depleted by the parent root. For less mobile ions (e.g. phosphate, $D_{e}<10^{-8} \mathrm{~cm}^{2} \cdot \mathrm{s}^{-1}$ ), the impact of the topology of the root system would be negligible because depletion zones for such ions are very narrow and all roots could access fresh, unexploited soil zones. These modelling experiments led Fitter [26] to suggest some ecological implications of root topology. Hence, differences in the topology of root systems (herringbone to dichotomous) could correspond to overall plant growth rates and their ability to adapt to various degrees of soil fertility (especially for mobile nutrients).

Phosphorus acquisition has been the most extensively studied process, at scales ranging from the root segment to the root system, which can be addressed via architectural modelling. In particular, elegant studies by Lynch and co-workers, combining experimental work and architectural modelling, gave a detailed portrait of soil exploration in relation with $\mathrm{P}$ acquisition for bean (for a review see [47]).

Combining architectural modelling and the time dependent expansion of the $\mathrm{P}$ depleted zone (Eq. (1), with $D_{e}=$ $10^{-8} \mathrm{~cm}^{2} \cdot \mathrm{s}^{-1}$ ), Ge et al. [29] studied the effect of altered gravitropism of basal roots (that varied from shallow to deep) on $\mathrm{P}$ acquisition efficiency. In the case of homogeneous $\mathrm{P}$ distributions in the soil profile, shallower root systems explored more soil (per unit root biomass) than deeper systems because less inter-root competition occurred in the former case (i.e. less overlapping depletion zones between neighbouring roots - Fig. 8 a-b). In the case of stratified soil $\mathrm{P}$ concentrations, with high $\mathrm{P}$ concentrations in the first $10 \mathrm{~cm}$, shallower root 


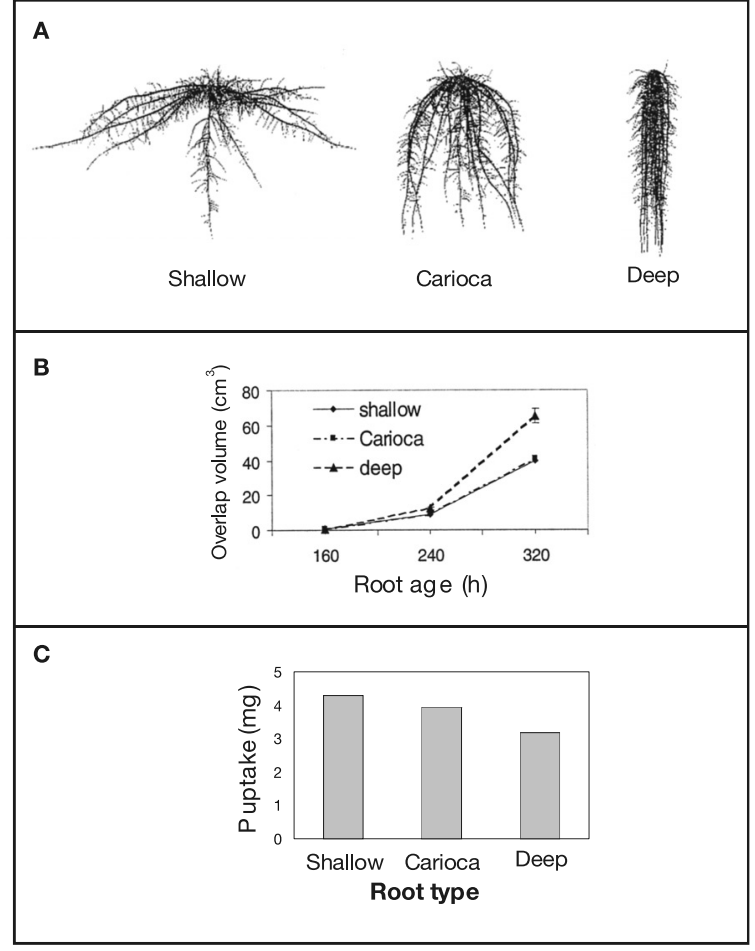

Figure 8. Simulation of the influence of different degree of basal root gravitropism on the exploitation of $\mathrm{P}$ by bean root systems. The depletion zone of $\mathrm{P}$ is represented by diffusion of $\mathrm{P}$ to the root with time (diffusion coefficient $=10^{-8} \mathrm{~cm}^{2} \cdot \mathrm{s}^{-1}$ ). A) Bean root systems simulated with different rooting pattern (shallow; Carioca, an actual cultivar, and deep). B) Volume of the overlapping exploited zones for the three root system types. C) P uptake by the three simulated root systems at the end of simulation $(320 \mathrm{~h})$, in the case of a stratified soil profile of $\mathrm{P}$ ( $\mathrm{P}$ concentration is higher in the first $20 \mathrm{~cm}$ of soil from [29]).

systems were also able to get more $\mathrm{P}$ because of increase foraging of the topsoil and less inter-root competition (Fig. $8 \mathrm{a}-\mathrm{c}$ ). Figure 9 shows the extent of depletion zones around bean roots and gives a visual idea of overlapping zones.

An example of the use of architectural modelling to dynamically predict uptake of more mobile nutrients is given by [77]. In this model, soil water and nitrate transport, nitrate uptake and the influence of nitrate availability on root growth are simulated (cf. Sect. 2.1.3). Figure 10 shows the simulated root system of a 25 day-old barley plant. Water and $\mathrm{NO}_{3}$ are supplied through drippers at the soil surface. In one scenario, $\mathrm{NO}_{3}$ is applied continuously (Fig. 10a), in the other $\mathrm{NO}_{3}$ is applied for a finite time at the beginning of the simulation. The total amounts of applied $\mathrm{N}$ are equal in the two cases. In the first case, simulations show that $\mathrm{N}$ concentrations are higher in the upper part of the soil and root density decreases with depth. In the second case, the $\mathrm{NO}_{3}$ plume moved downwards when application stopped and caused a greater root density in the central part of the soil. Interestingly, the maximum of root length density and $\mathrm{NO}_{3}$ concentration are shifted. This is linked to the relative rates of root growth and downwards percolation of $\mathrm{NO}_{3}$.

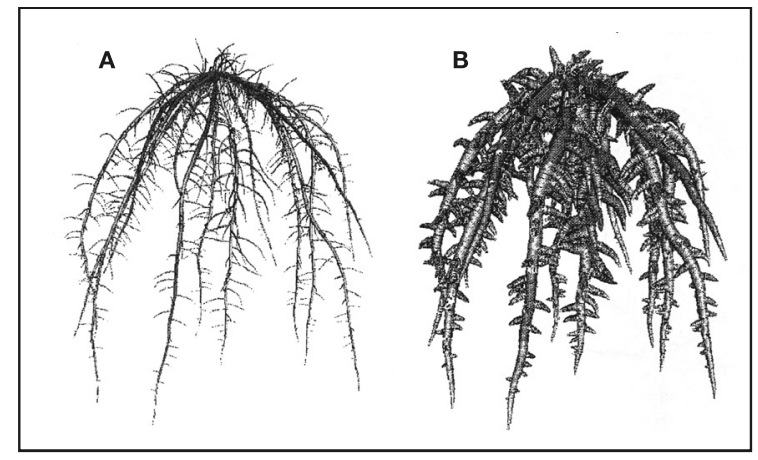

Figure 9. 3D representation of a simulated root system of bean and depletion zone of $\mathrm{P}$ around the roots (cf. Fig. 8) (from [46]).

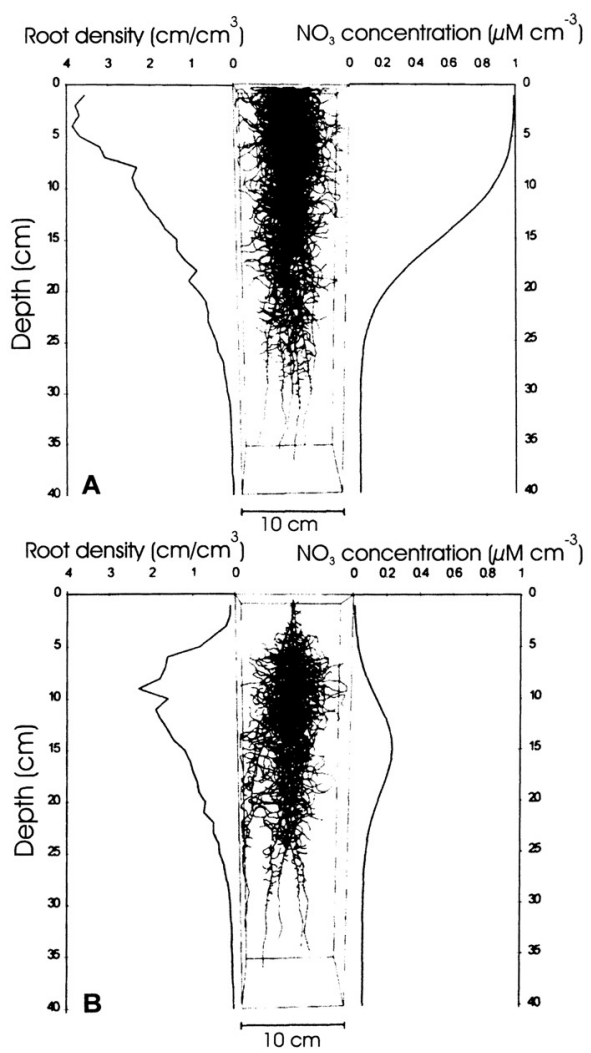

Figure 10. Simulated 3D root architecture (coupled with water and nitrate transfer and uptake by the root system) with corresponding root density and nitrate concentration distribution for (A) continuous supply of nitrogen by drippers and (B) the same amount of nitrogen, but supplied only at the beginning of the simulation period (from [77]).

\section{FROM SOIL EXPLORATION TO RESOURCE ACQUISITION}

Assessing soil exploration by plant roots would represent a convenient way to estimate resource acquisition if it could be assumed that all roots were equally and constantly involved in 
resources uptake (whatever the process investigated). However, it has been shown that for water or nitrate uptake, considering that all roots behave identically (a common assumption) and using ex-situ measured rates, would lead to over-estimating the actual uptake rates [70]. Based on actual uptake rates, it can be inferred that only $10 \%$ of the total root system length would be effectively involved in nitrate uptake and $30 \%$ in water uptake. But, as pointed out by Robinson [70], an important question is to determine which 10 and $30 \%$ parts of the root system are active?

As was shown in Section 3.1.2 for root growth and branching, a root system, should, from a functional viewpoint be regarded (i) as a population of individual roots behaving differently from each other [89], (ii) as a function of tissue differentiation and (iii) in response to changing environmental conditions (plasticity).

\subsection{Variations in root properties}

\subsubsection{Variations among root types}

Many reports show that different root types are functionally different. Leaf expansion of wheat is more impaired when drought affects seminal roots than nodal roots [88], and contribution of the seminal roots to the whole plant exceeds what could be expected from their fractal mass [89]. Navara [56] showed that radicle and seminal roots of maize play a dominant role in the water supply during a significant part of the plant life span. Nodal roots of maize were able to take up more phosphate from soil than radicle and seminal roots [55]. While the maximum uptake rate of barley for nitrate globally decreases between vegetative and reproductive growth stages, the nitrate uptake rate by nodal roots remains constant [51]. Lazof et al. [42] showed that nitrate uptake rates (per unit of dry weight) of the primary axis of young maize plant amount for $68 \%$ of the lateral uptake rate. Waisel and Eshel [90] showed variations in the uptake of $\mathrm{Cl}$ or $\mathrm{K}$ between taproot and laterals in pea. Mature lateral roots of maize lowered the $\mathrm{pH}$ at the soil-root interface, while their parent root made it more alkaline [50].

\subsubsection{Variations along roots}

Large variations in physiological properties exist along roots. These variations can be related to ontogenesis as root tissues get older, mature and differentiate, at increasing distances from the root tip [10]. Variations in growth rates between different root types and the way their tissues differentiate can also explain some of the variations in physiological/ metabolical properties between root types. Many processes were shown to vary along roots as a function of age, tissue structure and anatomical differentiation. High variations in root respiration were found along primary roots of Prunus persica [4], not only in the vicinity of the apex but up to about $20 \mathrm{~cm}$ from the tip. Parts of roots can release $\mathrm{H}^{+}$(acidification) while others release $\mathrm{OH}^{-}$depending on the available nitrogen resource [35]. $\mathrm{NO}_{3}$ and $\mathrm{NH}_{4}$ uptake was found to vary along roots, with defined zones of active (generally the apical zone) and passive uptake $[13,42]$. Variations in the uptake and translocation of other ions (P, K, Ca...) along roots were also dem-

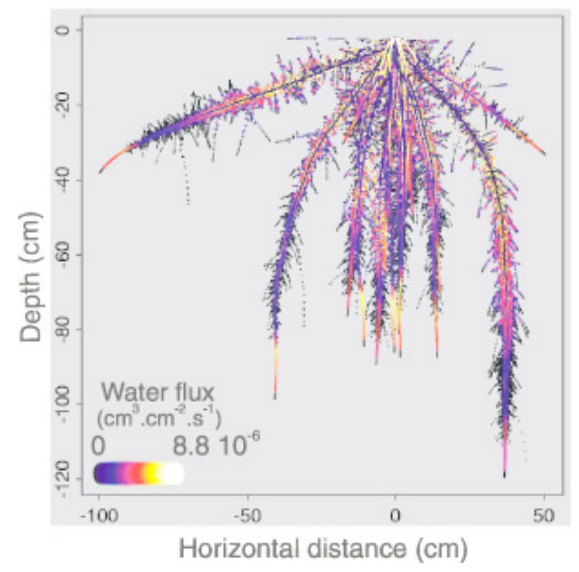

Figure 11. Distribution of water uptake within a simulated maize root system (43-day-old - 3D root system projected on a vertical plane). Water uptake is simulated by taking into account the variability of the root hydraulic conductance within the root system. The imposed transpiration is $5 \times 10^{-3} \mathrm{~cm}^{3} \cdot \mathrm{s}^{-1}$ and the water is freely available in the outside medium: water potential $=0 \mathrm{MPa}$. Even if water availability is uniform within the outside medium, uptake is heterogeneously distributed in the root system, showing hot-spot of uptake (from [20]). The figure is available in colour at: www.edpsciences.org/agro/.

onstrated [10]. In the field, cortical senescence in older root parts seems relatively common in cereals and other grasses [70]. Cortical senescence may weaken uptake because of physiological decrepitude but also by disrupting the transport pathway between the soil and the root.

The case of water uptake provides an illustrative example of how root functional heterogeneity can be taken into account in root system modelling. Water uptake along roots is related, for the radial pathway (water transport from soil to xylem vessels), to the differentiation of relatively impermeable structures (suberization) and for the axial pathway (water transport along roots), to xylem maturation [78]. In some monocot species, late metaxylem vessels (able to carry much of the water) were shown to open at large distances from the root tip (around 20-30 cm for main axes of maize [92]). Based on experimental data on water flow in maize roots [84] and architectural/ water transport modelling of the root system, Doussan et al. $[18,19]$ derived the variations of hydraulic conductance along maize primary and lateral roots, and showed the impact of these variations on the distribution of water uptake within the maize root system for the case of a uniform water avaiblity (Fig. 11). This figure shows the high heterogeneity of water uptake within the maize root system, even if water is uniformly available. Another type of pattern of water uptake was found for the perennial root system of a tree (Prunus), with most of the uptake located in the basal part of the root system [20]. Heterogeneity in the water uptake capacity along the root will have an impact on the way roots extract water from soil (Fig. 12 - [17]) and on variations of the environment (water potential and moisture content) in the vicinity of roots. This variations along a root may impact the rhizospheric activity and diversity. 


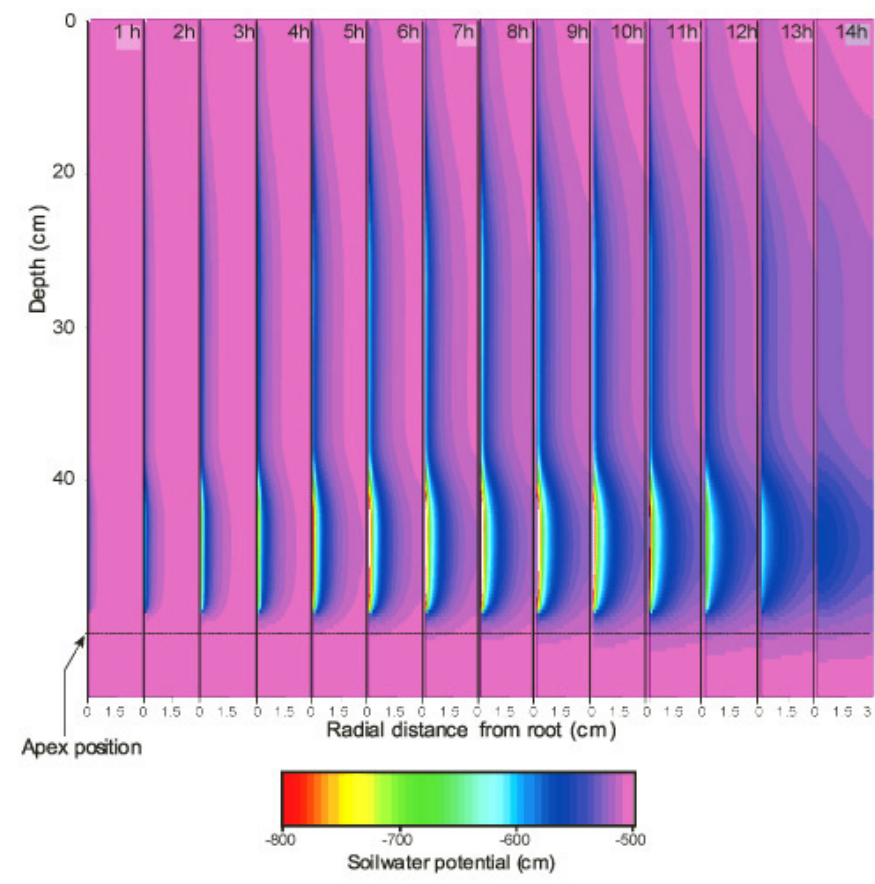

Figure 12. Simulated variation of water potential in soil for a single maize root axis (50 cm length, no laterals) during a $14 \mathrm{~h}$ simulation period. A sinusoidal variation (between -0.1 and $-1.2 \mathrm{MPa}$ ) of the xylem water potential is imposed at the root collar (similar to leaf water potential). The simulation couples water transfer in the soil and into/along the single root. The variations of the hydraulic conductance (axial and radial) along the maize root are included in the simulation and generate an heterogeneous pattern of uptake and water potential in the soil along the root, with greater variations near the root tip. The root axis is located at the left axis of each figure. The soil is a clay loam and the initial soil water potential is $-0.05 \mathrm{MPa}$ (from [17]). The figure is available in cobbotif at: www.edpsciences.org/agro/.

\subsection{Root system plasticity and uptake optimisation}

It is well known that plant roots systems are continuously subject to modifications following interactions with the environment. The function of this plasticity could be an adaptation to their sedentary life style to better explore their surroundings [43]. Root system plasticity should be considered in relation to soil conditions, but also in relation to competition with other species. Indeed, as shown for nitrate uptake under a wheat crop monoculture [73], plasticity does not necessarily imply a greater uptake: it can simply be triggered when competition with another species exists. Nutrient availability induces morphological variations of the root system. Parameters which can be affected are [27]: root branching, root growth (with growth of main axes generally less affected by nutritional effects than higher order axes), root diameter, root angle (for example, low $\mathrm{P}$ availability decreases the angle of emission of basal roots in bean, soybean and pea - [44]), root hair length and density, emission of specific root types (cluster roots - [75]; droughtinduced roots - [85]).

Plants response to spatial heterogeneity of nutrients has received much attention (see review by [71]). The influence of temporal variations in nutrient concentrations on root

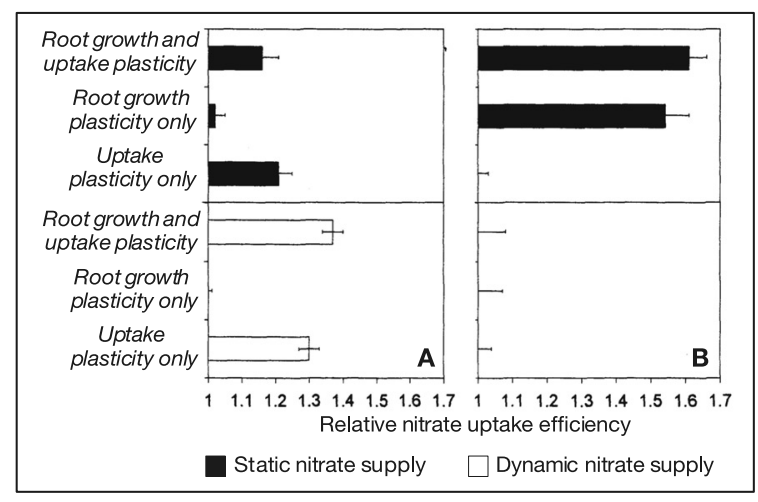

Figure 13. Simulation of nitrate uptake efficiency with an architecture model taking into account both inflow and morphological plasticity of the root system. Nitrate is distributed in the soil as small patches. The efficiency of uptake with plasticity is relative to the same root system with no plasticity response. Root systems are (A) herringbone system and (B) dichotomous system. In the dynamic supply case, the nutrient patches are randomly re-distributed in space, which is not the case for static supply (from [25]).

plasticity has been less studied. Experimental observations generally relate to conditions in which a small part of the root system has access to sufficient nutrients while the other is deprived [22]. Plant response in such a heterogeneous system happens at two time scales [72]: (i) a rapid and reversible physiological response within hours, which consists of an increase in nutrient inflow rate (high affinity transport), (ii) a slow morphological response within days, resulting in an increased root growth, and sometimes increased lateral density, towards and within the nutrient rich patch, associated with a reduced growth in the other part of the root system. However, if these responses are the global trend for plants, considerable variations in the intensity of these responses exist between species. The intensity of the response varies between no response to an order of magnitude variation (for growth or nutrient inflow) for the roots in the nutrient patch (see [72] for review). Stimulation of the inflow varies depending on the nutrient considered (and the duration of starvation). Root proliferation seems to depend less on the nutrient considered (except for $\mathrm{K}$ in some species). Localised responses such as root proliferation were generally explained in terms of nutritional effects [95]: roots directly exposed to the nutrient benefit the most from the increased $\mathrm{N}$ supply, or alternatively, the increased metabolic activity in those same roots increase the influx of carbohydrates and auxines. Recently, Zhang et al. [95] proposed a dual pathway for $\mathrm{NO}_{3}$ in Arabidopsis thaliana: a systemic inhibitory effect with $\mathrm{NO}_{3}$ accumulation and a localised stimulating effect, under genetic control, depending on $\mathrm{NO}_{3}$ concentration at the lateral root tip, where $\mathrm{NO}_{3}$ is directly the signal.

Interactions between nutrient availability and growth in architectural models have been presented by Somma et al. [77] and Dunbabin et al. [24]. In Somma et al.'s model [77] nitrate affects root growth out of an optimal range of concentration and elongation is scaled according to the amount of biomass allocated to the root system. The model by Dunbabin et al. [24] includes a more subtle description of root system plasticity. It 
uses the plant demand for individual resources and the ability of the various components of the root system to supply individual resources to drive the allocation of assimilates and subsequent architectural variations (root growth, branching) as well as nutrient uptake rates. This reproduces the dual pathway of a local 'sensing' response and a whole-plant response. Inflow plasticity and root proliferation plasticity are modelled. The model is based on Diggle's root architecture model ROOTMAP [15]. Nitrate is the nutrient taken into account and the model performance was assessed against laboratory data and validated in field experiments with Lupin species [23, 24]. An example of the results yielded by this model, applied to the extreme topological types of root systems (herringbone and dichotomous), is shown Figure 13 (from [25]). Nitrate is distributed in soil in random patches, with the same random profile (static supply) or a new rerandomised profile (dynamic supply), and applied every two days.

Interestingly, Figure 13 shows that incorporation of root and inflow plasticity in the root system behaviour makes the dichotomous system more efficient than the herringbone one in the case of static (heterogeneous) supply of nitrate. This contrasts with results of homogeneous supply (Fig. 7). On the contrary, in the case of dynamic $\mathrm{N}$ supply, the herringbone system is more efficient than the dichotomous one, and the latter gains almost no efficiency in uptake from plasticity.

\section{CONCLUSION}

Soil exploration and resource acquisition by plant roots result from both the dynamic expansion of the root system in space and the temporal variability of the root function/activity (between and along roots). Soil environmental conditions can also continuously modulate the pattern of exploration and exploitation by roots because of the constraints it imposes on root growth or because of root plasticity induced by resources heterogeneous availability. Plant adaptative strategies to locally sense environmental changes result in local responses but are co-ordinated at the whole plant level. All these plantsoil processes, with different time and space scales, can be integrated within the unifying framework of root system architecture.

Such integration is now possible because root system architecture models are widely available and become increasingly powerful tools which enable the simulation of root functioning, plasticity and interactions of roots with their environment. Such modelling tools provide a quantified view of soil-plant interactions, from the single root to the root system level, and can link local processes to global behaviour.

On the other hand, breakthrough technologies give more and more spatially detailed data on the functioning of root systems ex and in situ (e.g. non destructive imaging of the root system and its soil environment [65]; Cryo-scanning of soilroot system [52], microsensors [67]; root-pressure probes [78]). These new experimental data give new insight into root functioning and a sound basis for parameterisation and validation of distributed modelling of root systems at a range of scales.
As Lynch and Nielsen [48] pointed out, not all the interactions and processes of the plant-soil system can be simulated with the same degree of accuracy (however, this should be moderated considering the evolution of experimental devices and computing power). Progress can be achieved by focusing root models on some specific process, while approximating the general trend of other factors or interactions. Another challenging way for operational applications is to degrade the sophisticated root models, looking at the more important parameters, in order to get some simple but robust relationships (such as root - sink terms) adapted to some particular crop and soil settings.

Among the numerous processes which, so far, have only received little attention and which could be tackled via architectural modelling in relation with root exploration are:

- interactions between plants, arising either from intra or inter-specific competition including allelopathy, and resulting in profound modifications of root morphology [86];

- interactions with mycorrhyzae, which can alter root system architecture [33] and are able to access a very different range of soil pore sizes than roots (with possibly specific biogeochemical environments);

- mobilisation of nutrients by roots and modification of the soil environment (mucilage, release of acids, complexing agents... [31]) and their implications for soil properties near the roots;

- occurrence and functioning of new root types: Cluster roots, drought-induced roots, hairy roots...

Finally, much is to be understood about 'how real roots work' [53]. The in situ environment of roots may be quite different from what is generally accepted. For example, much research is need to improve our understanding of the development of rhizosheaths [52] and root colonisation of a relatively specific range of soil pores having specific biologic and physico-chemical properties (soil macropores and cracks, preceding root biopores, $[52,66,68])$.

\section{REFERENCES}

[1] Amstrong W., Drew M.C., Root growth and metabolism under oxygen deficiency, in: Waisel Y., Eshel A., Kafkafi U. (Eds.), Plant roots: the hidden half, Marcel Dekker Pub., 2002, pp. 729 762.

[2] Bengough A.G., Modelling rooting depth and soil strength in a drying soil profile, J. Biol. 186 (1997) 327-338.

[3] Bennie A.T.P., Growth and mechanical impedance, in: Waisel Y., Eshel A., Kafkafi U. (Eds.), Plant roots: the hidden half, Marcel Dekker Pub., 1996, pp. 453-470.

[4] Bidel L., Renault P., Pagès L., Rivière L.M., An improved method to measure spatial variation in root respiration: application to the taproot of a young peach tree Prunus persica, Agronomie 21 (2000) 179-192.

[5] Bowen G.D., Soil temperature, root growth and plant function, in: Waisel Y., Eshel A., Kafkafi U. (Eds.), Plant roots: the hidden half, Marcel Dekker Pub., 1991, pp. 309-329.

[6] Bruckler L., de Cockborne A.M., Renault P., Claudot B., Spatial and temporal variabilty of nitrate in irrigated salad crops, Irrig. Sci. 17 (1997) 53-61.

[7] Cannon W.A., A tentative classification of root sytems, Ecology 30 (1949) 452-458. 
[8] Castrignano A., Maiorana M., Fronaro F., Lopez N., 3D spatial variability of soil strength and its change over time in a durum wheat field in southern Italy, Soil Tillage Res. 65 (2002) 95-108.

[9] Chanzy A., Modélisation simplifiée de l'évaporation d'un sol nu en utilisant l'humidité et la température de surface accessible par télédétection, Ph.D. Thesis, INA- Paris-Grignon, 1991.

[10] Clarkson D.T., Root structure and sites of ion uptake, in: Waisel Y., Eshel A., Kafkafi U. (Eds.), Plant roots: the hidden half, Marcel Dekker Pub., 1996, pp. 483-510.

[11] Clausnitzer V., Hopmans J.W., Simultaneous modeling of transient three-dimensional root growth and soil water flow, Plant and Soil 164 (1994) 299-314.

[12] Cooper A.J., Root temperature and plant growth. A review, Research Review No. 4, Commonwealth Bureau of Horticulture and plantation crops, Commonwealth agricultural bureaux, Slough, UK, 1973.

[13] Cruz C., Lips S.H., Martins-Loucao M.A., Uptake of inorganic nitrogen in roots of carob seedlings, Physiol. Plant. 95 (1995) 167 175.

[14] De Willigen P., van Noordwijk M., Mass flow and diffusion of nutrients to a root with constant or zero-sink uptake, Soil Sci. 157 (1994) 162-175.

[15] Diggle A.J., ROOTMAP - a model in three-dimensional coordinates of the growth and structure of fibrous root systems, Plant and Soil 105 (1988) 169-178.

[16] Dittmer H.J., A quantitative study of the roots and root hairs of a winter ray plant (Secale Cereale), Am. J. Bot. 24 (1937) 417-420.

[17] Doussan C., Spatial and temporal evolution of root water uptake in relation with the heterogeneous distribution of water in soil, 16th Congrès Mondial de Science du Sol, 20-26 Août, Montpellier (France) 1998, Vol. II, 778

[18] Doussan C., Pagès L., Vercambre G., Modelling of the hydraulic architecture of root systems: An integrated approach to water absorption - 1. Model description, Ann. Bot. 81 (1998) 213-223.

[19] Doussan C., Vercambre G., Pagès L., Modelling of the hydraulic architecture of root systems: An integrated approach to water absorption - 2. Distribution of axial and radial conductances in maize, Ann. Bot. 81 (1998) 225-232.

[20] Doussan C., Vercambre G., Pagès L., Water uptake by two contrasting root systems (maize, peach tree): results from a model of hydraulic architecture, Agronomie 19 (1999) 255-263.

[21] Drew M.C., Plant injury and adaptation to oxygen deficiency in the root environment: A review, Plant and Soil 75 (1983) 179-199.

[22] Drew M.C., Saker L.R., Nutrient supply and the growth of the seminal root system in barley. II- Localised compensatory increases in lateral root growth and rates of nitrate uptake when nitrate supply is restricted to only one part of the root system, J. Exp. Bot. 26 (1975) 79-90.

[23] Dunbabin V., Diggle A.J., Rengel Z., Simulation of field data by a basic three-dimensional model of interactive root growth, Plant and Soil 239 (2002) 39-54.

[24] Dunbabin V., Diggle A.J., Rengel Z., van Hungten R., Modelling the interactions between water and nutrient uptake and root growth, Plant and Soil 239 (2002) 19-38.

[25] Dunbabin V., Diggle A., Rengel Z., Modelling responses to heterogeneous nutrient supply in three-dimensional space, in Proc. 6th Symp. Int. Soc. Root Res., 11-15 Nov. 2001, Nagoya, Japan, 2001, pp. 98-99.

[26] Fitter A., Characteristics and functions of roots systems, in: Waisel Y., Eshel A., Kafkafi U. (Eds.), Plant roots: the hidden half, Marcel Dekker Pub., 2002, pp. 15-32.

[27] Ford B., Lorenzo H., The nutritional control of root developement, Plant and Soil 232 (2001) 51-68.

[28] Foy C.D., Soil chemical factors limiting plant root growth, in Hatfield J.L., Stewart B.A. (Eds.), Limitations to plant root growth, Adv. Soil Sci. 19 (1992) 97-132.

[29] Ge Z., Rubio G., Lynch J.P., The importance of root gravitropism for inter-root competition and phosphorus acquisition efficiency: results from a geometric simulation model, Plant and Soil 218 (2000) 159-171.
[30] Harper J.L., Jones M., Hamilton N.R., The evolution of roots and the problem of analysing their behaviour, in: Atkinson D. (Ed.), Plant root growth: an ecological perspective, Special publication of the British ecological society No. 10, Blackwell scientific Pub., 1991, pp. 3-24.

[31] Hinsinger P., How do plant roots acquire mineral nutrients? Chemical processes involved in the rhizosphere, Adv. Agron. 64 (1998) 225-265

[32] Hoad S.P., Russel G., Lucas M.E., Bingham I.J., The management of wheat, barley and oat root systems, Adv. Agron. 74 (1992) 193246.

[33] Hooker J.E., Black K.E., Perry R.L., Atkinson D., Vesicular Arbuscular mycorrhizal fungi induced alteration in poplar root system morphology, Plant and Soil 145 (1992) 207-214.

[34] Jackson R.B., Caldwell M.M., Geostatistical patterns of soil heterogeneity around individual perenial roots, J. Ecol. 81 (1993) 683-692.

[35] Jaillard B., Schneider A., Mollier A., Pellerin S., Modélisation du prélèvement minéral par les plantes fondée sur le fonctionnement bio-physico-chimique de la rhizosphère, in: Maillard $\mathrm{P}$., Bonhomme R. (Eds.), Fonctionnement des peuplements végétaux sous contraintes environnementales, Colloques de l'INRA 93, 2000, pp. 253-287.

[36] Jourdan C., Rey H., Modelling and simulation of the architecture and development of the oil-palm (Elais guinensis Jacq.) root sytem. I- The model, Plant and Soil 190 (1997) 217-233.

[37] Jungk A.O., Dynamics of nutrient movement at soil-root interface, in: Waisel Y., Eshel A., Kafkafi U. (Eds.), Plant roots: the hidden half, Marcel Dekker Pub, 2002, pp. 587-616.

[38] Kaspar T.C., Bland W.L., Soil temperature and root growth, Soil Sci. 154 (1992) 290-299.

[39] Klepper B., Development and growth of crop root systems, in: Hatfield J.L., Stewart B.A. (Eds.), Limitations to plant root growth, Adv. Soil Sci. 19 (1992) 1-25.

[40] Krasil'Nikov, Soil micro organisms and higher plants, Academy of Science of USSR Pub., Moscou, 1958.

[41] Kutschera L., Wurzelatlas mitleleuropaïsher Ackerunkräuter und Kulturpflanzen, Verlag Pub., Franckfurt am Main, 1960.

[42] Lazof D., Rufty T.W., Redingbaugh M.G., Localization of nitrate absorption and translocation within morphological regions of corn roots, Plant Physiol. 100 (1992) 1251-1258.

[43] Leyser O., Fitter A., Roots are branching out in patches, Trends Plant Sci. 3 203-204.

[44] Liao H., Rubio G., Yan X., Cao A., Brown K.M., Lynch J.P., Effect of phosphorus avaibility on basal root shalowness in common bean, Plant and Soil 232 (2001) 69-79.

[45] Lynch J., Root architecture and plant productivity, Plant Physiol. 109 (1995) 7-13.

[46] Lynch J., Nielsen K.L., Simulation of root system architecture, in: Waisel Y., Eshel A., Kafkafi U. (Eds.), Plant roots: the hidden half, Marcel Dekker Pub., 1996, pp. 247-257.

[47] Lynch J.P., Brown K.M., Topsoil foraging - an architectural adaptation of plants to low phosphorus avaibility, Plant and Soil 237 (2001) 225-237.

[48] Lynch J.P., Nielsen K.L., Davis R.D., Jablokov A.G., SimRoot: modelling and visualization of botanical root systems, Plant and Soil 18 (1997) 139-151.

[49] Marschner H., Römheld V., Horst W.J., Martin P., Root-induced changes in the rhizosphere: importance for the mineral nutrition of plants, Z. Pflanzenernähr. Bodenk. 149 (1986) 441-456.

[50] Marschner H., Mineral nutrition of higher plants, Academic Press, London, 1990.

[51] Mattson M., Lundborg T., Larson C.M., Growth and development of seminal and crown root systems in $\mathrm{N}$ limited barley and their contribution to nitrate acquisition during vegetative and generative growth, Plant and Soil 151 (1993) 239-247.

[52] McCully M.E., Roots in soil: Unearthing the Complexities of Roots and Their Rhizospheres, Annu. Rev. Plant Physiol. Plant Mol. Biol. 50 (1999) 695-718. 
[53] McCully M.E., How do real roots work? Some new views of root structure, Plant Physiol. 109 (1995) 1-6.

[54] McMichael B.L., Burke J.J., Temperature effects on root growth, in: Waisel Y., Eshel A., Kafkafi U. (Eds.), Plant roots: the hidden half, Marcel Dekker Pub., 2002, pp. 717-728.

[55] Mistrik I., Mistrikova I., Uptake, transport and metabolim of phosphate by individual roots of Zea mays L., Biologia (Bratislava) 50 (1995) 419-426.

[56] Navara J., Participation of individual root types in water uptake by maize seedlings, Biologia (Bratislava) 42 (1987) 17-26.

[57] Pagès L., Root system architecture: from its representation to the study of its elaboration, Agronomie 19 (1999) 295-304.

[58] Pagès L., Modelling root system architecture, in: Waisel Y., Eshel A., Kafkafi U. (Eds.), Plant roots: the hidden half, Marcel Dekker Pub, 2002, pp. 359-382.

[59] Pagès L., Asseng S., Pellerin S., Diggle A., Modelling root system growth and architecture, in: Smit A.L., Bengough A.G., Engels C., van Noordwijk M., Pellerin S., van de Geijn S.C. (Eds.), Root methods: A handbook, Springer Pub., Paris, 2000, pp. 113-146.

[60] Pagès L., Doussan C., Vercambre G., Bruckler L., Habib R., Relations sol plante et absorption hydrique, in: Tiercelin J.R. (Ed.), Traité d'irrigation, éditions Techniques et Documentation, Lavoisier, 1998, pp. 88-111.

[61] Pagès L., Jordan M.O., Picard D., A simulation model of the three-dimensional architecture of the maize root system, Plant and Soil 119 (1989) 147-154.

[62] Pagès L., Le Roux Y., Thaler P., Modélisation de l'architecture racinaire de l'hévéa, Plante Rech. Dév. 2 (1995) 19-34.

[63] Pankurst C.E., Pierret A., Hawke B.G., Kirby J.M., Microbiological and chemical properties of soils associated with macropores at different depths in red duplex soil in NWS Australia, Plant and Soil 238 (2002) 11-20

[64] Parry S., Renault P., Chadoeuf J., Chenu C., Lensi R., Particulate organic matter as a source of variation in denitrification in clods of soils, Eur. J. Soil Sci. 51 (2000) 271-281.

[65] Pierret A., Doussan C., Garrigues E., Kirby J.M., Observing plant roots in their environment: current imaging options and perspectives, Agronomie (submitted).

[66] Pierret A., Moran C.J., Pankurst C.E., Differentiation of soil properties related to the spatial association of wheat roots and soil macropores, Plant and Soil 211 (1999) 51-58.

[67] Portefield D.M., Use of microsensors for studying the physiological activity of plant roots, in: Waisel Y., Eshel A., Kafkafi U. (Eds.), Plant roots: the hidden half, Marcel Dekker Pub, 2002, pp. 333-348.

[68] Rasse D.P., Smucker A.J.M., Root recolonization of previous root channels in corn and alfalfa rotation, Plant and Soil 204 (1998) 203-212.

[69] Robinson D., Phosphorus availability and cortical senescence in cereal roots, J. Theor. Biol. 145 (1990) 257-265.

[70] Robinson D., Roots and ressource fluxes in plants and communities, in: Atkinson D. (Ed.), Plant root growth: an ecological perspective, Special publication of the british ecological society No. 10, Blackwell scientific Pub., 1991, pp. 103-130.

[71] Robinson D., The response of plants to non-uniform supplies of nutrients, Tansley Review No. 73, New Phytol. 127 (1994) 635674.

[72] Robinson D., Variation, co-ordination and compensation in root systems in relation to soil variability, Plant and Soil (1987) 1996, $57-66$.

[73] Robinson D., Root proliferation, nitrate inflow and their carbon costs during nitrogen capture by competing plants in patchy soil, Plant and Soil 232 (2001) 41-50.

[73b] Schiefebein J.W., Benfey P.N., The development of plant roots New approaches to underground problems, Plant Cell 3 (1991) $1147-1154$

[74] Silberbush M., Simulation of ion uptake from the soil, in: Waisel Y., Eshel A., Kafkafi U. (Eds.), Plant roots: the hidden half, Marcel Dekker Pub., 2002, pp. 651-661.
[75] Skene K.R., Cluster roots: their physiology, ecology and developmental biology, Ann. Bot. 85 (2000) 899-909.

[76] Smit A.L., George E., Groenwold J., Root Observations and Measurements at (Tranparent) Interface with Soil, in: Smit A.L., Bengough A.G., Engels C., van Noordwijk M., Pellerin S., van de Geijn S.C. (Eds.), Root methods: A handbook, Springer Pub., Paris, 2000, pp. 235-273.

[77] Somma F., Hopmans J.W., Clausnitzer V., Transient threedimensional modeling of soil water and solute transport with simultaneous root growth, root water and nutrient uptake, Plant and Soil 202 (1998) 281-293.

[78] Steudle E., Water utake by roots: effects of water deficit, J. Exp. Bot. 51 (2000) 1531-1542.

[79] Stewart J.B., Moran C.J., Wood J.T., Macropore sheat: quantification of plant root and soil macropore association, Plant and Soil 211 (1999) 59-67.

[80] Tatsumi J., Fractal geometry of root system morphology: Fractal dimension and multifractals, Proc. 6th Symp. Int. Soc. Root Res. 11-15 Nov. 2001, Nagoya, Japan, 2001, pp. 24-25.

[81] Tatsumi J., Yamauchi A., Kono Y., Fractal analysis of plant root systems, Ann. Bot. 64 (1989) 499-503.

[81b] Tsutsumi D., Study on root system development by modelling approach, Ph.D. Thesis, Kyoto University, 2003, 135 p.

[82] Van Noordwijk M., Mulia R., Functional branch analysis as tool for fractal scaling above and belowground trees for their additive and non-additive properties, Ecol. Model. 149 (2002) 41-51.

[83] Van Vuuren M.M.I., Robinson D., Griffith B.S., Nutrient inflow and root proliferation during the exploitation of a temporally and spatially discrete source of nitrogen in soil, Plant and Soil 178 (1995) 185-192.

[84] Varney G.T., Canny M.J., Rates of water uptake into the mature root system of maize plants, New Phytol. 123 (1993) 775-786.

[85] Vartanian N., The drought rhizogenesis, in: Waisel Y., Eshel A., Kafkafi U. (Eds.), Plant roots: the hidden half, Marcel Dekker Pub., 1996, pp. 471-482.

[86] Vaughan D., Ord B.G., Extraction of potential allelochemicals and their effects on root morphology and nutrient contents, in Atkinson D. (Ed.), Plant root growth: an ecological perspective, Special publication of the british ecological society No. 10, Blackwell scientifivc Pub., pp. 399-422.

[87] Vercambre G., Pagès L., Doussan C., Habib R., Architectural analysis and synthesis of the plum tree root system in orchard using a quantitative modelling approach, Plant and Soil 251 (2003) 1-11.

[88] Volkmar K.M., Water stressed nodal roots of wheat: effects on leaf growth, Aust. J. Plant Physiol. 24 (1997) 49-56.

[89] Waisel Y., Eshel A., Functional diversity of various constituents of a single root system, in: Waisel Y., Eshel A., Kafkafi U. (Eds.), Plant roots: the hidden half, Marcel Dekker Pub., 2002, pp. 157174.

[90] Waisel Y., Eshel A., Differences in ion uptake among roots of various types, J. Plant Nutr. 15 (1992) 945-958.

[91] Weaver J.E., The ecological relations of roots, Carnegie Inst. Wash Pub. 26, 1919.

[92] Wenzel C.L., McCully M.E., Canny M.J., Development of water conducting capacity in the root systems of young plants of corn and some other C4 grasses, Plant Physiol. 89 (1989) 1084-1101.

[93] Wilcox H.E., Mycorrhizae, in: Waisel Y., Eshel A., Kafkafi U. (Eds.), Plant roots: the hidden half, Marcel Dekker Pub., 1996, pp. 689-722.

[94] Yanai R., A steady-state model of nutrient uptake accumulating for newly grown roots, Soil Sci. Soc. Am. J. 58 (1994) 1562-1571.

[95] Zhang H., Jennings A., Barlow P.W., Forde B.G., Dual pathways for regulation of root branching by nitrate, Proc. Natl. Acad. Sci. USA 96 (1999) 6529-6534.

[96] Zobel R.W., Soil environment constraints to root growth, in: Hatfield J.L., Stewart B.A. (Eds.), Limitations to plant root growth, Adv. Soil Sci. 19 (1992) 27-51. 